\title{
Entrepreneurial Knowledge and the Influence of Entrepreneurship Education on Students' Entrepreneurial Abilities
}

\author{
Changqing Lai ${ }^{1}$, Wenjing lv $^{1}$, Yuning Jiang ${ }^{2}$ \\ ${ }^{1}$ School of Economics and Management, Tsinghua University, Beijing, China \\ ${ }^{2}$ Key Lab of Integrated Microsystem Science \& Engineering Applications, Shenzhen Graduate School, Peking \\ University, Shenzhen, China \\ Email: laicq14@mails.tsinghua.edu.cn
}

Received 2 April 2015; accepted 28 June 2015; published 1 July 2015

\begin{abstract}
This paper studies the influence of entrepreneurship education on students' entrepreneurial abilities from the perspective of social network. In four college students' entrepreneurship case studies from one university, we adopted methodological triangulation and multiple methods to guarantee the reliability and validity of the research. We proposed that courses and projects in entrepreneurship education formed social network among mentors, monitors, and students, in which knowledge could flow frequently. We then discussed the influence of projects pattern, mentor pattern, and monitors pattern on college students' entrepreneurial abilities respectively, by analyzing the structure and ties of the social network. This research contributed to social network theory and entrepreneurship education both theoretically and practically.
\end{abstract}

\section{Keywords}

Social Network, Entrepreneurship Education, Entrepreneurial Abilities, Entrepreneurial Knowledge

\section{Introduction}

Since 2010, China's GDP has become the second in the world, and the country's economy development is more stable. Under this background, there are a lot of business opportunities, and the Chinese government has made many entrepreneurship support policies to encourage university students to start their businesses. However, an important problem is that entrepreneurial opportunities are springing up, but the university students' entrepreneurial abilities are not great enough to do so (Weihui, et al. 2009) [1]. Many researchers study the issue of entrepreneurship education. Especially important, a lot of researchers believe that entrepreneurship education should combine the courses with practice.

\section{Literature Review}

Junyi et al. (2011) make a classification of entrepreneurship education at home and abroad [2]. Entrepreneurship 
education models which combine courses with practice have three types. a) to cultivate entrepreneurial awareness, Babson represent them. b) develop practical experience, Harvard business school is one of their representatives. c) business knowledge training system, Stanford University is one of their representatives. In China, there are also three types of entrepreneur education models (Junyi et al. (2011)) [2]. Above all, universities should focus on developing students' consciousness of entrepreneurship, and build business knowledge structure, represented by Renmin University of China.

In the case of the central university of finance and economics, Jin (2008) gets some achievements and experience of the entrepreneurship education in the school [3]. Zhi-yuan (2008) studies region characteristics of entrepreneurship education about Wenzhou area [4]. Zhi-rong (2006) points out that entrepreneurship education, very need to establish entrepreneurship education system and to develop excellent teachers [5]. In recent years, our country comprehensively deepens education reform. In Huazhong University of science and technology, Pei-gen (2009) puts forward the student-centered education, and thinks that education needs to take the student as the basement [6]. Xian-jun (2012) argues that we need to regard student's learning and development as the center [7].

Network structure refers to the direct or indirect interaction mode between different bodies (Kalish and Robins, 2006; Klyver, 2008) [8] [9]. Granovetter (1973) puts forward the concept of weak ties, and use weak ties to describe the degree that main body acquire new information and ideas by interactions [10]. Granovetter (1973) points that weak tie whose distribution range is wide can fully access to information and other resources, so the weak link is worth more than strong ties [10]. Therefore, it is still a controversial position to discuss which is more important and valuable. Burt (1992) proposes the theory of structural holes and thinks that structural holes concepts are more directly than weak ties when building linking [11].

\section{Method}

This paper discussed the entrepreneurship education of Huazhong University of Science and Technology from September, 2008 to now as the background, whose applicability is: the educational ideology of this college is taking student as the center. Since 2008, Qiming College has been the important part of the entrepreneurship education of the university over the past 6 years, whose mode of entrepreneurship education has levelled off from production to development. Many other universities, such as Tsinghua University, the best university in China, have also achieved excellent result in entrepreneurship education. Tsinghua University has had favorable entrepreneurship education since 1998, but its educational pattern has never been stable. The most characteristic Xlab in Tsinghua University was founded up in 2013, less than 2 years up to now, whose effect of entrepreneurship education has not been favorably shown.

\subsection{Data}

To collect useful information, we collect several categories of date: 1) Newspapers about 4 teams and other news. 2) A large number of documents, including team yearbook, team summary, project journals of students, and meeting records of team. 3) Interview and communication. We have More than 10 interviews or informal communication with members of 4 teams and teachers. The objects of these interviews and communication include team mentors, monitors, students, personnel in enterprise, and other teachers and students who don't belong to the teams. 4) We attend internal activities of 4 teams and observe them on the spot. 5) Informal E-mails and telephones information.

\subsection{Data Analysis}

We analyze various events in the entrepreneurship education by interview, observation and data that we collect document and file. Then, we do triangle test to collected data, and require that important content must be confirmed by different data collection methods and different interviewees (Jick, 1979) [12].

As that we have mentioned above, in the process of illustration, we increase the comparison with existed bibliography to highlight the difference of our research. In the process of data analysis, we continuously circulate among data, bibliography and theory, until our theories and data can match well with each other (Ozcan and Eisenhardt, 2009) [13]. 


\subsection{Validity and Reliability}

Multiple methods are used to ensure the validity of research, including construct validity, internal validity and external validity.We establish database of case research to ensure the reliability of case research, and add repetition of our research. The requirements of reliability not refers to replicate our research result in another research, but to be able to let others to get the same research result by using our materials of case research (Table 1).

\section{Social Network, and Entrepreneurship Education}

\subsection{Entrepreneurship Education Model}

Resource dependence theory can tell us that people with high dependence are more likely to establish relationship to reduce the uncertainty of resource dependence (Pfeffer and Salancik, 1978) [14].

In the data of cases, we draw a conclusion that the most important three factors in entrepreneurship education are mentor, monitors, and projects. Students are taken as the objects who are affected by entrepreneurship education to open research.

From data collected by 4 student teams, we can explain how do mentors, monitors and ordinary students establish relationship through training projects to form small-scale network in entrepreneurship education (Table 2).

Table 1. Validity and reliability.

\begin{tabular}{|c|c|c|}
\hline \multicolumn{2}{|c|}{ Reliability analysis } & \multirow{2}{*}{$\begin{array}{l}\text { Validity analysis } \\
\text { Construct validity }\end{array}$} \\
\hline Design for case prototype & $\begin{array}{c}\text { Establishment of database for } \\
\text { the case study }\end{array}$ & \\
\hline $\begin{array}{l}\text { 1. Confirm team of research } \\
\text { 2. List and information of interviewees } \\
\text { 3. Outline of questions for interview } \\
\text { 4. Confirm activity that should be took part in } \\
\text { 5. Predicted data type and } \\
\text { design for acquiring methods } \\
\text { 6. Theoretical outline for major research content }\end{array}$ & $\begin{array}{l}\text { 1. Newspapers and news about teams } \\
\text { 2. Relevant files of teams } \\
\text { 3. Sound record information and written } \\
\text { information of interview } \\
\text { 4. Record information of activity } \\
\text { 5. E-mail and telephone information and } \\
\text { other supplementary information }\end{array}$ & $\begin{array}{l}\text { 1. Adopt multiple data sources to do cross } \\
\text { validation. } \\
\text { 2. Form evidence chain. } \\
\text { 3. Let major data providers to do validation } \\
\text { and check. } \\
\text { Internal validity: use the analysis method } \\
\text { of logical model to draw conclusion. } \\
\text { External validity: use replication logic. }\end{array}$ \\
\hline
\end{tabular}

Table 2. Data of four teams.

\begin{tabular}{|c|c|c|c|c|c|c|}
\hline Teams & $\begin{array}{l}\text { Establishment time } \\
\text { Whether to be exist } \\
\text { for a long time }\end{array}$ & $\begin{array}{l}\text { Time for entering } \\
\text { into Qiming } \\
\text { College }\end{array}$ & $\begin{array}{l}\text { Ideal of } \\
\text { entrepreneurship } \\
\text { education }\end{array}$ & Full-time mentors & $\begin{array}{l}\text { Source of } \\
\text { monitors }\end{array}$ & $\begin{array}{l}\text { Training projects for } \\
\text { entrepreneurship education }\end{array}$ \\
\hline $\begin{array}{l}\text { Dian } \\
\text { studio }\end{array}$ & $\begin{array}{l}\text { Established in } 2002 \\
\text { Last for a long time }\end{array}$ & 2008.09 & $\begin{array}{l}\text { Students- } \\
\text { centered }\end{array}$ & $\begin{array}{c}\text { Liu Yu } \\
\text { (Vice-president of } \\
\text { Qiming College) }\end{array}$ & $\begin{array}{l}\text { Senior students } \\
\text { in the team }\end{array}$ & $\begin{array}{l}\text { A large number of projects } \\
\text { with topic and outsource } \\
\text { projects of enterprise, such } \\
\text { as APP of China Mobile }\end{array}$ \\
\hline $\begin{array}{l}\text { Binyan } \\
\text { studio }\end{array}$ & $\begin{array}{l}\text { Established in } 1999 \\
\text { Last for a long time }\end{array}$ & 2008.09 & $\begin{array}{l}\text { Students- } \\
\text { centered }\end{array}$ & Li Binbin & $\begin{array}{l}\text { Senior students } \\
\text { in the team }\end{array}$ & $\begin{array}{l}\text { Products of campus: } \\
\text { Second-hand market in } \\
\text { campus, and campus news } \\
\text { network etc. }\end{array}$ \\
\hline $\begin{array}{l}\text { Unique } \\
\text { studio }\end{array}$ & $\begin{array}{l}\text { Established in } 2000 \\
\text { Last for a long time }\end{array}$ & 2008.09 & $\begin{array}{l}\text { Students- } \\
\text { centered }\end{array}$ & $\begin{array}{l}\text { With mentors } \\
\text { Mentors will be } \\
\text { changed often. }\end{array}$ & $\begin{array}{l}\text { Senior students } \\
\text { in the team }\end{array}$ & $\begin{array}{l}\text { Products combing software } \\
\text { and hardware. } \\
\text { Scientific innovation } \\
\text { products that take part in } \\
\text { Competition of Microsoft } \\
\text { Innovation Prize. }\end{array}$ \\
\hline Wechat fruit & $\begin{array}{l}\text { Established in } 2013 \\
\text { when project started } \\
\text { The team is a short- } \\
\text { term term. The team } \\
\text { will leave campus no } \\
\text { matter starting } \\
\text { business succeeds } \\
\text { or not. }\end{array}$ & No & None & $\begin{array}{l}\text { With mentors } \\
\text { But times for } \\
\text { guidance of } \\
\text { mentors are } \\
\text { limited. }\end{array}$ & $\begin{array}{l}\text { Without } \\
\text { mentors }\end{array}$ & $\begin{array}{l}\text { Wechat Fruit: } \\
\text { Students can buy fruits } \\
\text { through this APP. }\end{array}$ \\
\hline
\end{tabular}




\subsection{Social Network and Projects}

Through courses and projects of the entrepreneurship education, mentor, monitors and students build the ties. As for a series of entrepreneurship courses and interactions with students, mentor builds ties with each student. Some is strong ties and others are weak ties. In particular, the mentor build strong ties with monitors and most ordinary students establish weak ties with the mentor. In order to put the enterprise and government resources into entrepreneurship education, the mentor will establish new ties with some entrepreneurs and some government officials. Of course, there are some ties that mentors build with entrepreneurs and government officials in the original. Monitors teach other students. As a result, they established their strong ties with students (Figure 1 and Figure 2).

In particular, the projects play an important role in the entrepreneurship education. Mentors guide the students and tell them what kind of project is the need of society and worth doing. Monitors teach students how to do a projects, and teach them how to design a product, how to write the code if they do IT projects.

Proposition 1a: Training projects improve students' entrepreneurial thinking ability, and improve students' entrepreneurial practical ability by leading students to be in a clique.

Proposition 1b: Types of projects in entrepreneurship education affect students' matching direction of ability of starting business. Training projects of IT mainly improve students' ability of starting business relative to IT, such as ability relative to write codes and design websites.

\begin{tabular}{|l|l|}
\hline \multicolumn{2}{|c|}{$\begin{array}{c}\text { Student-centered Entrepreneurship } \\
\text { Education }\end{array}$} \\
\hline Mentors \\
Monitorial system \\
Project
\end{tabular}

Figure 1. Student-centered entrepreneurship education model in HUST.

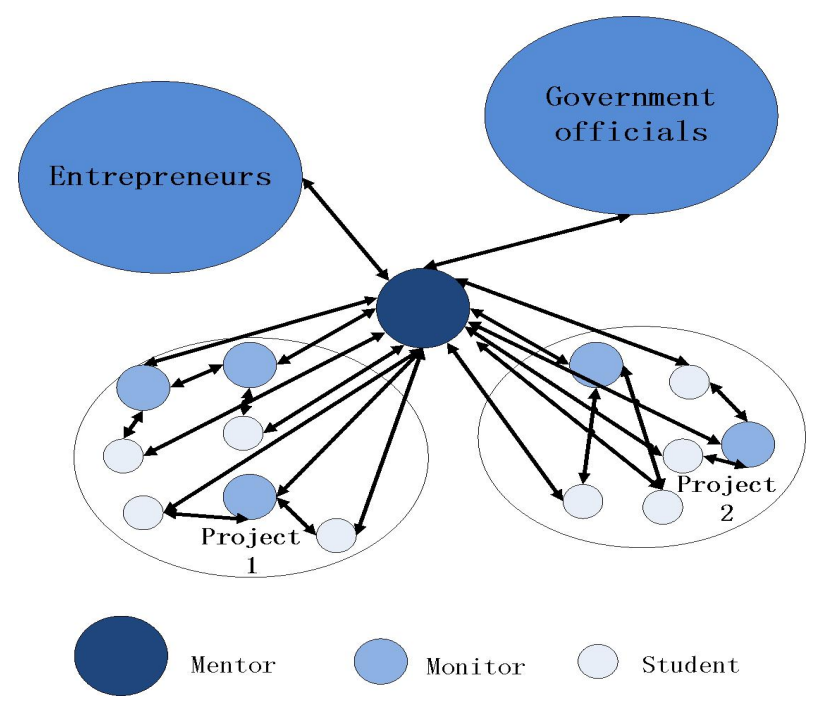

Figure 2. Network of mentor, monitors and students. 


\subsection{The Structure Position of the Mentor}

The previous research has pointed out that mentors educate students' ability of entrepreneurial thinking in the entrepreneurship education. But there is no research which can point out that how this effect generates. Our collected data shows the process of establishment of relationship between mentors and students. "Mentors use courses of entrepreneurship and face-to-face communication to teach me how to select entrepreneurship programs and companions of entrepreneurship." Students from Dian studio speak highly of mentors, who maintain that mentors are indispensable in their entrepreneurship education. A student from Bingyan Studio said "it is hard to meet mentors. Mentors seem to be busy doing their own affairs all the time, and seldom pay attention to us". Members from Wechat Fruits said that "although we are starting a business all the time and find mentors, mentors seldom meet with us, and their guidance is only symbolic".

Proposition 2a: Stronger the ties between the mentor and students becomes, bigger the improvement of students' ability of entrepreneurial thinking that entrepreneurship education gives is. It is those students who actively speak in class or often ask mentor for advice after class to establish strong ties with mentors. Most of these students become monitors.

Proposition 2b: Mentors have the structure advantages. Stronger the relationship between the mentor and these external personnel such as entrepreneurs and government officials is, larger the improvement of student's ability of entrepreneurial thinking that entrepreneurship education gives is (Table 3).

\subsection{The Structure Position of Monitors}

Monitor system has been studied in many literatures, which is thought to have obvious effect in education. If they become monitors, it is only helpful for teachers, because they can help teachers to relieve burden of work. Therefore, the meaning of becoming monitors will reduce sharply, and there will be fewer students who are willing to become monitors. Our research shows that monitors can use their strong relationship with mentors and structure advantage in circle to acquire better education and resource in the entrepreneurship education.

Monitors bring students in junior grades to complete projects that are introduced by mentors from enterprise or mentors design. In the training of projects, what monitors educate is students' executive ability for entrepreneurship. Students from Bingyan studio said "monitors taught us a lot. The most impressive is that he taught me to write java codes, and told me the meaning of each code."

Proposition 3a: Becoming monitors can establish strong relationship with students they guide. Through this strong relationship, monitors can improve students' practical ability of entrepreneurship. During the process of teaching students, monitors' practical ability of entrepreneurship is improved.

Proposition 3b: Monitors can use their own structure advantage to acquire resources in different small cliques. This experience improves monitors' practical ability of entrepreneurship.

\section{Discussion}

Based on the perspective of social network, this paper proposes a theoretical framework that how entrepreneurship education affects students' entrepreneurial abilities, which makes contribution to scientific guidance of social network in theory development of field of entrepreneurship education and practical guidance of college entrepreneurship education.

Table 3. Information of mentors of the 4 teams.

\begin{tabular}{|c|c|c|c|}
\hline Teams & $\begin{array}{c}\text { The degree of participation of } \\
\text { mentors }\end{array}$ & $\begin{array}{l}\text { Times that mentor invites entrepreneurs or } \\
\text { government officers to come to teams to } \\
\text { guide students }\end{array}$ & $\begin{array}{l}\text { The degree of help that } \\
\text { students get from entrepreneurs } \\
\text { and government officers }\end{array}$ \\
\hline $\begin{array}{l}\text { Dian } \\
\text { studio }\end{array}$ & High & Many & High \\
\hline $\begin{array}{l}\text { Bingyan } \\
\text { studio }\end{array}$ & Medium & Medium & Medium \\
\hline $\begin{array}{l}\text { Unique } \\
\text { studio }\end{array}$ & Low & Few & Low \\
\hline Wechat fruits & Almost none & Zero & Zero \\
\hline
\end{tabular}




\subsection{Scientific Implications and Practical Implications}

This paper exerts a certain scientific effect on theoretical development of social network in entrepreneurship education. Few previous researchers studied it by combining social network and entrepreneurship education. In fact, through courses and projects of entrepreneurship education, mentors, monitors and students form their network. In this network, mentors, monitors and projects affect students respectively. Those tutors who have structure advantage can invite entrepreneurs and government officers, affecting students' entrepreneurial abilities.

\subsection{Limitations and Future Research}

As the article is a qualitative article based on case analysis, which lacks quantitative statistics, the correctness of theory needs to get the support from more quantitative studies.

The future studies can analyze the effect of mentors, monitors and projects on starting of business of students respectively from the perspective of social network. Especially we should research the effect of mentors and monitors with different characteristics on effects of entrepreneurship education. Besides, the future studies can research the effect of entrepreneurship education on improvement of students' entrepreneurial abilities under the situation that mentors possess different circles which cause the difference of network structure advantages.

\section{References}

[1] Weihui, M., candidate, D., University, Z., Xiaozhou, X., Dean, A.V., \& professor, et al. (2009) Problems and Strategies of Entrepreneurship Education in Higher Institutions in China. Educational Research.

[2] Lu, J.Y. and Wang, Y.G., Chen, Z.W. and Wang, J.J. (2011) Construction of University Entrepreneurship Education Model Based on All-Round Social Participation in China. Chinese Journal of Management.

[3] Jin, X., Director, management, P., Research, University, C., \& Economics. (2008) Entrepreneurship Education Mode in Higher Education Institutions-Based on Case Study. Educational Research.

[4] Zhi-yuan, X. and Zhi-yuan, X. I. E. (2008) Constructing "Wenzhou Model” of Entrepreneurship Education of Undergraduates. Journal of Higher Education, 5, 018.

[5] Zhi-rong, M. U. (2006) Research on the Mode of Entrepreneurship Education for Undergraduates in China. Journal of Higher Education, 11, 013.

[6] Pei-gen, L. (2009) Recognizing the Higher Education from the Foundation. Journal of Higher Education.

[7] Xian-jun, L. (2012) On the Student-Centered Ideal. Journal of Higher Education.

[8] Kalish, Y. and Robins, G. (2006) Psychological Predispositions and Network Structure: The Relationship between Individual Predispositions, Structural Holes and Network Closure. Social Networks, 28, 56-84. http://dx.doi.org/10.1016/j.socnet.2005.04.004

[9] Klyver, K., Hindle, K. and Meyer, D. (2008) Influence of Social Network Structure on Entrepreneurship Participation-A Study of 20 National Cultures. International Entrepreneurship and Management Journal, 4, 331-347. http://dx.doi.org/10.1007/s11365-007-0053-0

[10] Granovetter, M.S. (1973) The Strength of Weak Ties. American Journal of Sociology, 1360-1380. http://dx.doi.org/10.1086/225469

[11] Burt, R.S. (1992) Structural Holes: The Social Structure of Competition. Harvard University Press.

[12] Jick, T.D. (1979) Mixing Qualitative and Quantitative Methods: Triangulation in Action. Administrative Science Quarterly, 24, 602-611. http://dx.doi.org/10.2307/2392366

[13] Ozcan, P. and Eisenhardt, K.M. (2009) Origin of Alliance Portfolios: Entrepreneurs, Network Strategies, and Firm Performance. Academy of Management Journal, 52, 246-279. http://dx.doi.org/10.5465/AMJ.2009.37308021

[14] Salancik, G.R. and Pfeffer, J. (1978) A Social Information Processing Approach to Job Attitudes and Task Design. Administrative Science Quarterly, 23, 224-253. http://dx.doi.org/10.2307/2392563 